\title{
Analisis Sektor Unggulan Aceh Bagian Timur
}

\author{
Nurlina \\ Fakultas Ekonomi Universitas Samudra \\ e-mail: nurlina@unsam.ac.id \\ Puti Andiny \\ Fakultas Ekonomi Universitas Samudra \\ e-mail: putiandiny@unsam.ac.id \\ Maulia Sari \\ Fakultas Ekonomi Universitas Samudra \\ e-mail: muliaasari8@gmail.com
}

\begin{abstract}
This study aims to analyze the leading sectors in the economy in Eastern Aceh. The data analysis method used is Location Quotient (LQ) analysis and Shift Share analysis. Based on the calculation of $L Q$, it is known that the leading sector of East Aceh Regency is the mining sector and the $L Q$ excavation from 2010-2016 with an average of 1,68 (LQ>1). This is because the availability of mineral content in East Aceh Regency increases the regional economy. The leading sector of Langsa City is health services and social activities with an average LQ since 2010-2016 of 2,10 (LQ>1). The leading sector of Aceh Tamiang Regency is the mining sector and excavation with an average LQ from 2010-2016 of 1,77 (LQ>1). Based on the shift share analysis, it is explained that the highest sector providing an increase in Aceh's GDRP was in the agriculture, forestry and fisheries sectors, and it was in the East Aceh District and Aceh Tamiang District, while Langsa City was not included. The sector that contributes to the increase in Aceh's GDRP, in Langsa City the sector that provides the highest increase in Aceh's GDRP is the sector of large and retail trade, car and motorcycle repair.
\end{abstract}

Keywords: Eastern Aceh, LQ, leading sector, shift share

\section{PENDAHULUAN}

Pembangunan ekonomi daerah adalah suatu proses di mana pemerintah daerah dan masyarakat mengelola sumberdaya-sumber daya yang ada, dengan menjalin pola-pola kemitraan antara pemerintah daerah dan pihak swasta guna penciptaan lapangan kerja, serta dapat merangsang pertumbuhan ekonomi di daerah bersangkutan. Keberhasilan pembangunan ekonomi daerah, sangat ditentukan oleh kebijakan-kebijakan pembangunan yang berlandaskan berbagai upaya meningkatkan pertumbuhan ekonomi yang mampu untuk menciptakan lapangan kerja secara optimal dari segi jumlah, produktivitas dan efisiensi.

Suatu negara selalu menginginkan perekonomian yang maju dalam usaha meningkatkan taraf pendapatan masyarakat sehingga dapat mewujudkan kesejahteraan. Maka pembangunan ekonomi sangat penting dilakukan dalam mencapai sasaran tersebut. Pembangunan ekonomi memiliki sasaran dalam meningkatkan kecerdasan, taraf hidup hingga kesejahteraan masyarakat.

Pembangunan ekonomi daerah dapat melibatkan multisektor serta para pelaku pembangunan, sehingga diperlukan jaring 
kerjasama dan koordinasi di antara semua pihak yang berkepentingan. Sejak era reformasi terjadi pergeseran paradigma dalam sistem penyelenggaraan pemerintahan dari pola sentralisasi menjadi pola desentralisasi ataupun disebut otonomi daerah yang mengandung makna, beralihnya sebagian besar proses pengambilan keputusan dalam perencanaan, pelaksanaan serta evaluasi penyelenggaraan pemerintahan dari pusat ke daerah.

Pertumbuhan ekonomi dan prosesnya yang berkelanjutan merupakan kondisi utama bagi kelangsungan pembangunan ekonomi daerah. Jumlah penduduk terus bertambah dan berarti kebutuhan ekonomi juga bertambah, sehingga dibutuhkan penambahan pendapatan setiap tahun. Pendapatan tambahan tersebut dapat diperoleh dengan peningkatan output agregat (barang dan jasa) atau Produk Domestik Regional Bruto (PDRB) setiap tahun.

Aceh Bagian Timur terletak di sisi timur Aceh terdiri dari dua Kabupaten dan satu Kota yaitu Kabupaten Aceh Timur, Aceh Tamiang dan Kota Langsa. Pertumbuhan ekonomi ketiga Kabupaten/Kota itu berbeda, misalnya pada tahun 2016 pertumbuhan ekonomi Kota Langsa adalah lebih besar dibandingkan kabupaten Aceh Timur dan Aceh Tamiang. Padahal dengan banyaknya perusahaan yang berdiri di kabupaten Aceh Timur dan Aceh Tamiang seharusnya dapat meningkatkan pertumbuhan ekonomi di daerah tersebut. Perbedaan pertumbuhan ekonomi tersebut menjadi hal yang menarik untuk membandingkan sektor unggulan yang ada pada Kabupaten/Kota tersebut.

Sebagai sarana penunjang kegiatan perekonomian, di Kabupaten Aceh Timur tersedia satu pelabuhan, yaitu Pelabuhan Idi. Untuk industri tersedia 6 (enam) kawasan industri, yaitu kawasan industri UMKM pisang sale, kawasan industri kelapa terpadu, kawasan industri pengolahan rotan, kawasan industri agro dan perikanan, Kawasan Industri Kelapa Terpadu Timur (KITAT) dan kawasan industri migas pertambangan dan energi yang didukung juga oleh fasilitas listrik dan telekomunikasi. Pertumbuhan ekonomi pada Kabupaten Aceh Timur pada tahun 2014-
2016 mengalami penurunan, masing-masing adalah sebesar $0,51 \%, 5,98 \%$ dan $1,35 \%$. Penurunan pada nilai PDRB Aceh Timur disebabkan oleh penurunan drastis pada kategori pertanian, kehutanan dan perikanan karena adanya faktor cuaca dan bencana alam seperti banjir yang berdampak kepada penurunan produksi beberapa komoditas utama.

Kota Langsa terbentuk secara definitif pada tanggal 21 Juni 2001, berdasarkan Undang-Undang Nomor 3 Tahun 2001. Kedudukan Kota Langsa yang berada di lintas jalan nasional di wilayah pantai Timur Aceh, merupakan suatu nilai strategis sebagai potensi sekaligus peluang yang perlu dimanfaatkan secara optimal. Dalam posisi tersebut, Kota Langsa semestinya dapat menjadi pusat pertumbuhan ekonomi terbesar di wilayah pantai timur Aceh, dengan memanfaatkan peluang strategis dari keberadaan daerah hinterland di sekitarnya, terutama Kabupaten Aceh Timur dan Aceh Tamiang.

Dari sisi lain, letak geografis kota langsa yang dikelilingi Selat Malaka, tepatnya pada bagian utara, merupakan potensi dan peluang yang sangat besar untuk mewujudkan arus perputaran orang, barang dan jasa melalui jalur laut, baik antar Wilayah di pantai timur Aceh, pulau Sumatera dan pulaupulau lain di Indonesia, maupun kegiatan perdagangan internasional (ekspor-impor) dengan negara-negara lain, seperti Malaysia dan lainnya. Hal itu sangat memungkinkan untuk diwujudkan, mengingat saat ini Kota Langsa telah memiliki fasilitas pelabuhan laut Kuala Langsa, berikutnya dengan sejumlah infrastruktur penunjang yang memadai.

Pertumbuhan ekonomi merupakan laju pertumbuhan yang dibentuk dari berbagai macam sektor ekonomi. Perkembangan sektor ekonomi sendiri secara tidak langsung menggambarkan tingkat pertumbuhan yang terjadi sebagai indikator penting bagi Kota Langsa untuk mengevaluasi keberhasilan pembangunan. Perkembangan PDRB Kota Langsa pada tahun 2014-2016 mengalami peningkatan secara signifikan yaitu masingmasing sebesar 4,24\%, 4,42\%, dan 4,50\%. Hal ini disebabkan laju pertumbuhan ekonomi 
mengalami pertumbuhan dari berbagai sektor yang memegang peranan terbesar dalam aktivitas perekonomian di Kota Langsa mulai dari Perdagangan Besar dan Eceran, Reparasi Mobil dan Sepeda Motor, Industri Pengolahan, Konstruksi, Transportasi Pergudangan, serta Pertanian, Kehutanan, dan Perikanan.

Kabupaten Aceh Tamiang merupakan kawasan kaya minyak dan gas, meski jumlahnya tidak sebesar Kabupaten Aceh Utara, dan kawasan ini juga merupakan salah satu pusat perkebunan kelapa sawit di Aceh. Di samping itu, Aceh Tamiang juga mengandalkan sektor angkutan karena posisinya yang strategis, dan angkutan air merupakan salah satu primadona alternatif karena kabupaten ini dialiri dua sungai besar yakni Sungai Tamiang (yang terpecah menjadi Simpang Kiri dan Simpang Kanan) dan Sungai Kaloy.

Kabupaten Aceh Tamiang juga mengandalkan sektor pertanian, industri pengolahan dan perdagangan. Kabupaten ini memiliki berbagai potensi, diantaranya potensi minyak dan gas alam, juga memiliki batu bara, bijih besi, batu gamping, fosfat, lempung, batu lanau, pasir, kerikil, batu kali dan energi panas bumi (geotermal).

Perkembangan PDRB Kabupaten Aceh Tamiang pada tahun 2014-2016 mengalami peningkatan yaitu masing-masing sebesar $2,40 \%, 2,63 \%$ dan 2,85\%, hal ini disebabkan laju pertumbuhan ekonomi dari beberapa sektor Kabupaten Aceh Tamiang masih di dominasi oleh kategori Pertanian, Kehutanan, dan Perikanan, Pertambangan dan Penggalian, Perdagangan Besar dan Eceran; Reparasi Mobil dan Sepeda Motor, Industri pengolahan serta konstruksi yang terus berkembang.

Berdasarkan uraian pada latar belakang, adapun tujuan penelitian ini adalah:

1. Menganalisis sektor unggulan dalam perekonomian di Aceh Bagian Timur.

2. Menganalisis sektor-sektor apa saja yang memberikan daya saing terbesar di Aceh Bagian Timur.

\section{Konsep Regional}

Rustiadi (2007:48) menyebutkan bahwa konsep regional adalah cabang ilmu yang mempelajari aspek-aspek dan kaidah-kaidah kewilayahan, dan mencari data-data yang efektif dalam mempertimbangkan aspekaspek kaidah-kaidah tersebut ke dalam proses perencanaan pengembangan kualitas hidup dan kehidupan manusia.

Secara umum, terdapat 4 (empat) bentuk wilayah yang banyak digunakan dalam analisa ekonomi regional, yaitu (Sjafrizal, 2008:54):

1. Homogeneous region, yaitu kesatuan wilayah yang dibentuk dengan tujuan memperhatikan kesamaan karakteristik sosial-ekonomi dalam wilayah yang bersangkutan. Termasuk ke dalam wilayah seperti ini antara lain adalah: provinsi, kota, kabupaten dan desa. Sedangkan pada tingkat internasional, termasuk dalam wilayah ini adalah kesatuan beberapa negara seperti ASEAN, European Union dan lain-lainnya.

2. Nodal region, yaitu kesatuan wilayah yang dibentuk berdasarkan keterkaitan sosial-ekonomi yang erat antar daerah. Keterkaitan ini menjadi penting karena dapat mendorong terbentuknya kesatuan yang erat antara beberapa daerah atau negara terkait.

3. Planning region, yaitu kesatuan wilayah yang dibentuk untuk tujuan penyusunan perencanaan pembangunan. Termasuk ke dalam wilayah ini antara lain adalah: wilayah pembangunan dalam perencanaan pembangunan baik pada tingkat nasional maupun tingkat provinsi atau kabupaten dan kota.

4. Administrative region, yaitu kesatuan wilayah yang dibentuk berdasarkan pertimbangan kemampuan dan kebutuhan administrasi pemerintahan. Termasuk ke dalam wilayah ini adalah provinsi, kabupaten, kota, kecamatan, dan desa.

\section{Pengertian Sektor Unggulan}

Pengertian sektor unggulan biasanya berkaitan dengan suatu perbandingan, baik itu perbandingan berskala regional, nasional maupun internasional. Pada lingkup internasional, suatu sektor dikatakan unggulan jika sektor tersebut mampu bersaing dengan sektor yang sama dengan negara lain. Sedangkan pada lingkup nasional, suatu 
sektor dapat dikategorikan sebagai sektor unggulan apabila sektor di wilayah tertentu mampu bersaing dengan sektor yang sama yang dihasilkan oleh wilayah lain, baik di pasar nasional ataupun domestik (Tambunan, 2001:11). Sektor unggulan adalah sektor yang mampu mendorong pertumbuhan atau perkembangan bagi sektor-sektor lainnya, baik sektor yang mensuplai inputnya maupun sektor yang memanfaatkan outputnya sebagai input dalam proses produksinya (Widodo, 2006:141).

Sektor unggulan sebagai sektor yang sangat penting dalam pembangunan ekonomi suatu wilayah tidak hanya mengacu pada lokasi secara geografis saja melainan merupakan suatu sektor yang menyebar dalam berbagai saluran ekonomi sehingga mampu menggerakkan ekonomi secara keseluruhan. Sambodo (dalam Firman, 2007:141), ciri-ciri sektor yang memiliki keunggulan adalah sebagai berikut:

1. Sektor itu memiliki laju pertumbuhan ekonomi yang tinggi.

2. Sektor itu memiliki angka penyebaran yang relatif besar.

3. Sektor itu memiliki keterkaitan antar sektor yang tinggi baik keterkaitan depan ataupun kebelakang.

Suatu daerah akan mempunyai sektor unggulan apabila daerah tersebut dapat memenangkan persaingan pada sektor yang sama dengan daerah lain sehingga dapat menghasilkan ekspor (Suyatno, 2000:4). Sektor unggulan dipastikan memiliki potensi lebih besar untuk tumbuh lebih cepat dibandingkan sektor lainnya dalam suatu daerah terutama adanya faktor pendukung terhadap sektor unggulan tersebut yaitu akumulasi modal, pertumbuhan tenaga kerja yang terserap, dan kemajuan teknologi (technological progress).

\section{Kriteria Penentuan Sektor Unggulan}

Sektor unggulan menurut Sambodo (dalam Usya, 2006:12) memiliki beberapa kriteria. Pertama, sektor unggulan memiliki laju pertumbuhan ekonomi yang tinggi. Kedua, sektor unggulan memiliki angka penyerapan tenaga kerja yang relatif besar. Ketiga, sektor unggulan memiliki keterkaitan antara sektor yang tinggi baik ke depan maupun ke belakang. Keempat, sektor yang mampu menciptakan nilai tambah yang tinggi.

Menurut Rachbini (2001:10), terdapat empat syarat agar suatu sektor tertentu menjadi sektor prioritas, yaitu:

1. Sektor itu harus menghasilkan produk yang mempunyai permintaan yang cukup besar sehingga laju pertumbuhan bisa berkembang cepat akibat dari efek permintaan tersebut.

2. Karena ada perubahan teknologi yang teradopsi secara kreatif maka fungsi produksi baru bergeser dengan sebab pengembangan kapasitas yang lebih luas.

3. Harus terjadi peningkatan investasi kembali dari hasil-hasil produksi sektor yang menjadi prioritas tersebut, baik swasta maupun pemerintah.

4. Sektor itu harus berkembang sehingga mampu memberi pengaruh terhadap sektor-sektor lainnya.

Menurut Ambardi dan Socia (2002:13), kriteria komoditas unggulan suatu daerah, diantaranya:

1. Komoditas unggulan harus mampu menjadi penggerak utama pembangunan perekonomian. Hal ini berarti komoditas unggulan dapat memberikan kontribusi yang signifikan pada upaya peningkatan produksi, pendapatan serta pengeluaran.

2. Komoditas unggulan memiliki keterkaitan ke depan dan ke belakang yang kuat, baik sesama komoditas unggulan maupun komoditas lainnya.

3. Komoditas unggulan mampu bersaing dengan produk sejenis dari wilayah lain di dalam pasar nasional dan pasar internasional, baik dalam harga produk, biaya produksi, kualitas pelayanan, maupun aspek-aspek lainnya.

4. Komoditas unggulan daerah memiliki keterkaitan dengan daerah lain, baik dalam hal pasar (konsumen) maupun pemasokan bahan baku (jika bahan baku di daerah sendiri tidak mencukupi atau tidak tersedia sama sekali).

5. Komoditas unggulan memiliki status teknologi yang terus meningkat, terutama melalui inovasi teknologi. 
6. Komoditas unggulan mampu menyerap tenaga kerja berkualitas secara optimal sesuai dengan skala produksinya.

7. Komoditas unggulan bisa bertahan dalam jangka waktu tertentu, mulai dari fase kelahiran, pertumbuhan, puncak hingga penurunan. Di saat komoditas unggulan yang satu memasuki tahap penurunan, maka komoditas unggulan lainnya harus mampu menggantikannya.

8. Komoditas unggulan tidak rentan terhadap gejolak eksternal dan internal.

9. Pengembangan komoditas unggulan harus mendapatkan berbagai bentuk dukungan. Misalnya, dukungan keamanan, sosial, budaya, informasi dan peluang pasar, kelembagaan, fasilitas insentif/disinsentif, dan lain-lain.

10. Pengembangan komoditas unggulan ber orientasi pada kelestarian sumber daya dan lingkungan.

\section{Teori Pembangunan Ekonomi}

Pembangunan ekonomi daerah adalah suatu proses dimana pemerintah daerah dan masyarakatnya mengelola sumber dayasumber daya yang ada dan membentuk suatu pola kemitraan antara pemerintah daerah dan sektor swasta dalam rangka menciptakan lapangan kerja baru serta demi merangsang perkembangan kegiatan-kegiatan ekonomi (pertumbuhan ekonomi) dalam wilayah tersebut (Arsyad, 1999:108).

Pembangunan ekonomi daerah seharusnya berorientasi pada proses. Suatu proses yang melibatkan pembentukan institusi baru, pembangunan industri alternatif, perbaikan kapasitas tenaga kerja yang ada untuk menghasilkan produk yang lebih baik, identifikasi pasar-pasar baru, dan proses transformasi pengetahuan (Adisasmita, 2005:19). Pembangunan ekonomi daerah merupakan fungsi dari potensi sumberdaya alam, tenaga kerja dan sumberdaya manusia, investasi modal, prasarana dan sarana pembangunan, transportasi dan komunikasi, komposisi industri, teknologi, situasi ekonomi dan perdagangan antar wilayah, kemampuan pendanaan dan pembiayaan pembangunan daerah, kewirausahaan, kelembagaan daerah dan lingkungan pembangunan secara luas.
Potensi ekonomi suatu daerah adalah kemampuan ekonomi yang ada di daerah yang mungkin dan layak dikembangkan sehingga akan terus berkembang menjadi sumber penghidupan rakyat setempat bahkan dapat menolong perekonomian daerah secara keseluruhan untuk berkembang dengan sendirinya dan bersifat berkesinambungan (Soeparmoko, 2002).

\section{Perubahan Struktur Ekonomi Daerah}

Pertumbuhan ekonomi yang dapat berlangsung secara berkesinambungan dalam suatu kurun waktu tertentu dapat mengubah struktur ekonomi. Keadaan ekonomi di negara manapun umumnya mengalami pertumbuhan baik secara alamiah maupun pengaruh dari kebijakan ekonomi. Perubahan struktur (transformasi struktural) atas pola perekonomian suatu daerah adalah perubahan dari sistem ekonomi tradisional ke sistem ekonomi modern. Ini berarti juga terjadi perubahan struktur ekonomi dari sektor pertanian ke sektor industri kemudian dari sektor industri berubah ke sektor jasa-jasa (Sirojuzilam \& Mahalli, 2010:19).

Dalam proses pembangunan daerah selain mempertimbangkan pertumbuhan dan pemerataan, juga dampak aktivitas ekonomi terhadap kehidupan sosial masyarakat. Lebih jauh, dalam pelaksanaan pembangunan seharusnya dilakukan upaya yang bertujuan untuk mengubah struktur perekonomian kepada arah yang lebih baik (Kuncoro, 2003:19).

\section{Teori Basis Ekonomi}

Menurut Saharuddin (2005:196), teori basis ekonomi terdapat dua sektor kegiatan, yaitu sektor basis ekonomi dan sektor nonbasis ekonomi. Sektor basis merupakan sektor yang memiliki potensi besar dalam menentukan pembangunan menyeluruh di daerah, sedangkan sektor nonbasis merupakan sektor penunjang dalam pembangunan menyeluruh tersebut. Kegiatan basis merupakan kegiatan yang berorientasi ekspor barang dan jasa ke luar batas wilayah perekonomian yang bersangkutan karena sektor ini telah mencukupi kebutuhan di dalam wilayah tersebut. Kegiatan nonbasis 
adalah kegiatan menyediakan barang dan jasa yang dibutuhkan oleh masyarakat yang berada dalam batas wilayah perekonomian yang bersangkutan tanpa melakukan ekspor ke luar wilayah karena kemampuan sektor tersebut untuk mencukupi kebutuhan lokal masih terbatas. Luas lingkup produksi dan pemasarannya bersifat lokal. Penganjur pertama teori basis ekspor murni adalah Tiebout yang kemudian di kembangkan dalam pengertian ekonomi regional, di mana ekspor di artikan sebagai kegiatan menjual produk/jasa keluar wilayah baik ke wilayah lain dalam negara itu maupun keluar negeri. Tenaga kerja yang berdomisili di wilayah kita, tetapi bekerja dan memperoleh uang dan wilayah lain termasuk dalam pengertian ekspor. Pada dasarnya kegiatan ekspor adalah semua kegiatan baik penghasil produk maupun penyedia jasa yang mendatangkan uang dari luar wilayah di sebut kegiatan basis.

Sirojuzilam (2010:20) mengatakan beberapa aktivitas ekonomi di dalam suatu wilayah secara khusus merupakan aktivitasaktivitas basis ekonomi, yaitu dalam arti pertumbuhannya memimpin dan menentukan perkembangan wilayah secara keseluruhan, sementara aktivitas-aktivitas lainnya yang non basis adalah secara sederhana merupakan konsekuensi dari keseluruhan perkembangan wilayah tersebut. Teori ini merupakan salah satu pendekatan yang bertujuan untuk menjelaskan perkembangan dan pertumbuhan wilayah.

Aktivitas basis memiliki peranan sebagai penggerak utama (primer mover) dalam pola pertumbuhan suatu wilayah. Semakin besar ekspor suatu wilayah ke wilayah lain akan semakin maju pertumbuhan wilayah tersebut, demikian sebaliknya. Setiap perubahan yang terjadi pada sektor basis akan menimbulkan efek ganda (multiplier effect) dalam aktivitas perekonomian regional (Adisasmita, 2005:21).

Teori basis ekonomi berupaya untuk menemukan dan mengenali aktivitas basis dari suatu wilayah, kemudian meramalkan aktivitas itu dan menganalisis dampak tambahan dari aktivitas ekspor tersebut. Konsep kunci dari teori basis ekonomi adalah bahwa kegiatan ekspor merupakan mesin pertumbuhan. Tumbuh atau tidaknya suatu wilayah ditentukan oleh bagaimana kinerja wilayah itu terhadap permintaan akan barang dan jasa dari luar.

Salah satu cara dalam menentukan suatu sektor sebagai sektor basis atau non-basis adalah analisis Location Quotient (LQ). Arsyad (1999:21) menjelaskan bahwa teknik Location Quotient dapat membagi kegiatan ekonomi suatu daerah menjadi dua golongan yaitu:

1. Kegiatan sektor ekonomi yang melayani pasar di daerah itu sendiri maupun di luar daerah bersangkutan. Sektor ekonomi seperti ini dinamakan sektor ekonomi potensial (basis).

2. Kegiatan sektor ekonomi yang melayani pasar di daerah tersebut dinamakan sektor tidak potensial (non basis).

\section{Produk Domestik Regional Bruto}

Produk Domestik Regional Bruto (PDRB) merupakan produksi yang dihasilkan oleh suatu masyarakat dalam kurun waktu satu tahun yang berada di daerah atau regional tertentu. Angka Produk Domestik Regional Bruto sangat dibutuhkan dan perlu disajikan, karena selain dapat dipakai sebagai bahan analisa perencanaan pembangunan juga merupakan barometer untuk mengukur hasilhasil pembangunan yang telah dilaksanakan.

Produk domestik regional bruto (PDRB) merupakan satu indikator ekonomi untuk mengukur kemajuan pembangunan di suatu wilayah. Selain nilai dari semua barang dan jasa yang dihasilkan sektor-sektor ekonomi, PDRB bermanfaat untuk mengetahui tingkat produk netto atau nilai tambah yang dihasilkan oleh seluruh faktor produksi, besarnya laju pertumbuhan ekonomi, dan pola (struktur) perekonomian pada satu tahun periode tertentu di suatu negara atau wilayah tertentu, Prihatin (dalam Azis, 2012:22).

Penyajian PDRB terdapat dua cara, yaitu PDRB Atas Dasar Harga Konstan (ADHK), artinya semua agregat pendapatan dinilai atas dasar harga tetap, sehingga perkembangan agregat pendapatan dari tahun ke tahun semata-mata karena perkembangan produksi riil bukan karena kenaikan harga 
atau inflasi. Atau dengan kata lain PDRB atas dasar harga konstan adalah jumlah nilai produksi atau pendapatan atau pengeluaran yang dinilai atas dasar harga tetap (harga pada tahun dasar) yang digunakan selama satu tahun. Sedangkan PDRB Atas Dasar Harga Berlaku (ADHB) adalah jumlah nilai produksi atau pendapatan (pengeluaran) yang dinilai sesuai dengan harga yang berlaku pada tahun yang bersangkutan.

Penghitungan PDRB atas dasar harga konstan berguna untuk menggambarkan tingkat pertumbuhan perekonomian suatu daerah baik secara agregat (keseluruhan) maupun sektor. Selain itu juga bermanfaat untuk menganalisis perubahan struktur perekonomian suatu daerah berdasarkan distribusi masing-masing sektor ekonomi terhadap nilai total PDRB. Selain itu, pendapatan per kapita yang diperoleh dari perbandingan PDRB atas dasar harga berlaku dengan jumlah penduduk pada tahun bersangkutan dapat digunakan untuk membandingkan tingkat kemakmuran suatu daerah dengan daerah lainnya. Perbandingan PDRB atas dasar harga berlaku terhadap PDRB atas dasar harga konstan dapat juga digunakan untuk melihat inflasi atau deflasi yang terjadi.

\section{METODE PENELITIAN}

Penelitian ini membahas tentang sektor unggulan Aceh Bagian Timur, dengan lokasi penelitian di Aceh Bagian Timur yaitu Kabupaten Aceh Timur, Kota Langsa, dan Kabupaten Aceh Tamiang.

Jenis dan Sumber data pada penelitian ini adalah data sekunder yang diperoleh dari Badan Pusat Statistik Aceh (BPS Aceh).

\section{Metode Analisis Data}

Metode analisis data dalam penelitian ini menggunakan:

\section{1) Analisis Location Quotient (LQ)}

Location Quotient (LQ) adalah perbandingan peran sektor/industridi suatu daerah terhadap besarnya peran sector atau industri tersebut secara nasional (Tarigan, 2014: 82).
Dalam mengukur LQ menggunakan pendekatan nilai tambah atau PDRB (Tarigan, 2009 dalam Dodik, 2012) adalah sebagai berikut:

$$
L Q n=(\mathrm{Vi} / \mathrm{Vt}) /(\mathrm{Yi} / \mathrm{Yt})
$$

dimana:

Vi : Nilai PDRB sektor i pada tingkat wilayah yang rendah

Vt : Nilai PDRB pada tingkat wilayah yang lebih rendah

Yi : Nilai PDRB sektor i pada tingkat wilayah yang lebih atas

Yt : Total PDRB pada tingkat PDRB yang lebih atas

Nilai dari Location Quotient (LQ) adalah (Tarigan, 2014: 82-83):

- LQ > 1, artinya peranan sektor tersebut lebih besar di daerah dari pada nasional.

- LQ < 1, artinya peranan sektor tersebut lebih kecil di daerah dari pada nasional.

- $\mathrm{LQ}=1$, artinya peranan sektor tersebut sama baik di daerah ataupun secara nasional

\section{2) Analisis Shift Share}

Menurut Tarigan (2004:197), analisis shift share membandingkan perbedaan laju pertumbuhan berbagai sektor di daerah dengan wilayah nasional.

Arsyad (1999:197) mengatakan analisis ini memberikan data tentang kinerja perekonomian dalam 3 (tiga) bidang yang berhubungan satu sama lain, yaitu:

1. Agregat secara sektoral dibandingkan dengan perubahan pada sektor yang sama di perekonomian yang di jadikan acuan.

2. Evaluasi Pergeseran Proporsional (Proportional Shift) mengukur perubahan relatif atas perubahan atau penurunan pada suatu daerah di bandingkan dengan perekonomian yang lebih besar yang dijadikan acuan. Teknik pengukuran ini memungkinkan peneliti mengetahui apakah perekonomian suatu daerah 
terkonsentrasi pada industri-industri yang tumbuh lebih cepat ketimbang perekonomian yang di jadikan acuan.

3. Evaluasi Pergeseran Diferensial (Differential Shift) membantu peneliti dalam menentuka seberapa jauh dayasaing industri daerah (local) dengan perekonomian yang di jadikan acuan. Oleh karena itu, jika pergeseran diferensial dari suatu industri adalah positif, maka industri tersebut lebih tinggi daya saingnya ketimbang industri yang sama padaperekonomian yang di jadikan acuan.

Metode shift-share digunakan untuk menganalisis ekonomi regional dengan formulasi sebagai berikut (John P. Blair dalam Sjafrizal, 2008:91):

$$
\mathrm{Dij}=\mathrm{Nij}+\mathrm{Mij}+\mathrm{Cij}
$$

Bila analisis tersebut diterapkan kepada Produk Domestik Regional Bruto (PDRB), Y, maka:

$$
\begin{aligned}
& \text { Dij = Y*ij - Yij .... } \\
& \text { Nij = Yij. rn ........ } \\
& \text { Mij = Yij (rin - rn) } \\
& \text { Cij = Yij (rij - rin) }
\end{aligned}
$$

dimana rij, rin dan $r n$ mewakili laju pertumbuhan wilayah provinsi dan nasional yang mana masing-masing didefinisikan sebagai berikut:

$$
\begin{aligned}
& \operatorname{rij}=(Y * i j-Y i j) / Y i j \\
& \text { rin }=\left(Y^{*} \text { in }-Y i n\right) / Y i n \\
& \mathrm{rn}=\left(\mathrm{Y}^{*} \mathrm{n}-\mathrm{Yn}\right) / \mathrm{Yn} \\
& \text { Yij = PDRB sektor } i \text { di wilayah } \\
& \text { provinsi, } \\
& \text { Yin }=\text { PDRB sektor } i \text { di tingkat } \\
& \text { nasional, } \\
& \text { Yn }=\text { PDRB di tingkat nasional, }
\end{aligned}
$$

Persamaan shift-share untuk sektor $i$ di Provinsi adalah:

$D i j=Y i j . r n+Y i j(r i n-r n)+Y i j(r i j-r i n)(9)$

Kriteria penilaian adalah:

- Jika Mij > 0 maka pertumbuhan sektor $i$ cepat pada wilayah Provinsi
- Jika Mij < 0 maka pertumbuhan sektor $i$ lambat pada wilayah Provinsi

- Jika Cij > 0 berarti sektor/wilayah $j$ mempunyai daya saing yang baik dibandingkan dengan sektor/wilayah provinsi lainnya untuk sektor $i$

- Jika Cij > 0 berarti sektor $i$ pada wilayah provinsi tidak dapat bersaing dengan baik dibandingkan dengan wilayah provinsi lainnya

\section{HASIL ANALISIS}

\section{Perkembangan Perekonomian}

Perkembangan PDRB Kabupatan Aceh Timur

Perkembangan PDRB Kabupaten Aceh

Timur dapat dilihat pada Tabel 1.

Tabel 1. Perkembangan PDRB Kabupaten Aceh Timur atas Dasar Harga Konstan Tahun 2010-2016

\begin{tabular}{ccc}
\hline Tahun & $\begin{array}{c}\text { PDRB } \\
\text { (Rupiah) }\end{array}$ & $\begin{array}{c}\text { Perkembangan } \\
(\%)\end{array}$ \\
\hline 2010 & $7.290 .035,9$ & - \\
2011 & $7.479 .287,2$ & 2,60 \\
2012 & $7.677 .933,9$ & 2,66 \\
2013 & $7.761 .221,1$ & 1,08 \\
2014 & $7.721 .422,5$ & $-0,51$ \\
2015 & $7.259 .933,9$ & $-5,98$ \\
2016 & $7.161 .994,7$ & $-1,35$ \\
\hline
\end{tabular}

Sumber: BPS Kabupaten Aceh Timur, 2018

Berdasarkan Tabel 1 dapat dijelaskan bahwa PDRB Kabupaten Aceh Timur pada tahun 2011 meningkat 2,60\%, pada tahun 2012 PDRB meningkat sebesar $2,66 \%$, namun pada tahun 2013 hanya meningkat sebesar 1,08\%. PDRB Kabupaten Aceh Timur kembali mengalami penurunan pada tahun 2014, 2015, 2016 masing-masing sebesar $0,51 \%, 5,98 \%$, dan $1,35 \%$. Penurunan PDRB Kabupaten Aceh Timur yang signifikan pada tahun 2015 yang mencapai 5,98\% disebabkan karena penurunan nilai sektor pertambangan dan penggalian dibandingkan tahun 2014. Sedangkan peningkatan tertinggi pada tahun 2012 dikarenakan meningkatnya infrastruktur dan jasa-jasa perusahaan yang ada di Kabupaten Aceh Timur. 
Perkembangan PDRB Kota Langsa

Perkembangan PDRB Kota Langsa dapat dilihat pada Tabel 2 .

Tabel 2. Perkembangan PDRB Kota Langsa atas Dasar Harga Konstan Tahun 2010-2016

\begin{tabular}{ccc}
\hline Tahun & $\begin{array}{c}\text { PDRB } \\
\text { (Rupiah) }\end{array}$ & $\begin{array}{c}\text { Perkembangan } \\
(\%)\end{array}$ \\
\hline 2010 & $2.609 .185,1$ & - \\
2011 & $2.722 .522,9$ & 4,34 \\
2012 & $2.851 .123,2$ & 4,72 \\
2013 & $2.981 .532,2$ & 4,57 \\
2014 & $3.107 .821,1$ & 4,24 \\
2015 & $3.245 .320,3$ & 4,42 \\
2016 & $3.391 .384,6$ & 4,50 \\
\hline
\end{tabular}

Sumber: BPS Kota Langsa, 2018

Berdasarkan Tabel 2. dapat dijelaskan bahwa PDRB Kota Langsa pada tahun 2011 meningkat sebesar 4,34\%. Pada tahun 2012 PDRB mengalami peningkatan dibandingkan tahun sebelumnya yaitu sebesar $4,72 \%$. Namun pada tahun 2013 PDRB Kota Langsa hanya meningkat $4,57 \%$ dan pada tahun 2014 hanya meningkatan 4,24\%. Pada tahun 2015 dan 2016, PDRB kembali mengalami peningkatan masing-masing sebesar 4,42\% dan 4,50\%. Rendahnya PDRB Kota Langsa pada tahun 2014 yang hanya meningkat 4,24\% dikarenakan lambatnya pembangunan sarana dan prasarana pertanian di Kota Langsa. Di sisi lain peningkatan PDRB tertinggi pada tahun 2012 disebabkan karena meningkatnya sektor jasa konstruksi di Kota Langsa.

\section{Perkembangan PDRB Kabupaten Aceh Tamiang}

Berdasarkan Tabel 3 dapat dijelaskan bahwa PDRB Kabupaten Aceh Tamiang pada tahun 2011 yaitu $1,53 \%$, pada tahun 2012 PDRB meningkat sebesar 3,96\%. Peningkatan PDRB Kabupaten Aceh Tamiang pada tahun 2013 cukup signifikan yaitu sebesar 5,04\%, namun pada tahun 2014 PDRB hanya meningkat sebesar 2,40\%. Pada tahun 2015 PDRB Kabupaten Aceh Tamiang hanya meningkat 2,63\% dan pada tahun 2016 mengalami peningkatan kembali sebesar 2,85\%. Rendahnya PDRB Kabupaten Aceh Tamiang pada tahun 2011 karena lambatnya pertumbuhan beberapa sektor seperti sektor konstruksi serta pertambangan.

Perkembangan PDRB Kabupaten Aceh Tamiang dapat dilihat pada Tabel 3.

\begin{tabular}{ccc}
$\begin{array}{r}\text { Tabel 3. Perkembangan PDRB Kabupaten } \\
\text { Aceh Tamiang atas Dasar Harga } \\
\text { Konstan Tahun 2010-2016 }\end{array}$ \\
\hline \multirow{2}{*}{ Tahun } & $\begin{array}{c}\text { PDRB } \\
\text { (Rupiah) }\end{array}$ & $\begin{array}{c}\text { Perkembangan } \\
(\%)\end{array}$ \\
\hline 2010 & $4.406 .760,5$ & - \\
2011 & $4.474 .076,2$ & 1,53 \\
2012 & $4.651 .203,2$ & 3,96 \\
2013 & $4.885 .618,6$ & 5,04 \\
2014 & $5.002 .816,8$ & 2,40 \\
2015 & $5.134 .529,8$ & 2,63 \\
2016 & $5.280 .861,3$ & 2,85
\end{tabular}

Sumber: BPS Kab. Aceh Tamiang, 2018

\section{Perkembangan PDRB Provinsi Aceh}

Perkembangan PDRB Provinsi Aceh pada tahun 2011 PDRB Provinsi Aceh meningkat sebesar 3,28\%, pada tahun 2012 PDRB meningkat $3,85 \%$, pada tahun 2013 PDRB meningkat $2,61 \%$, pada tahun 2014 PDRB meningkat $1,55 \%$. Namun pada tahun 2015 PDRB mengalami penurunan sebesar 0,73\%, dan pada tahun 2016 PDRB kembali mengalami peningkatan yaitu sebesar 3,31\%.

Tabel 4. Perkembangan PDRB Provinsi Aceh atas Dasar Harga Konstan Tahun 2010-2016

\begin{tabular}{ccc}
\hline Tahun & $\begin{array}{c}\text { PDRB } \\
\text { (Rupiah) }\end{array}$ & $\begin{array}{c}\text { Perkembangan } \\
(\%)\end{array}$ \\
\hline 2010 & $101.545 .236,8$ & - \\
2011 & $104.874 .211,2$ & 3,28 \\
2012 & $108.914 .897,6$ & 3,85 \\
2013 & $111.755 .826,6$ & 2,61 \\
2014 & $113.490 .359,3$ & 1,55 \\
2015 & $112.661 .039,6$ & $-0,73$ \\
2016 & $116.386 .730,6$ & 3,31 \\
\hline
\end{tabular}

Sumber: BPS Provinsi Aceh, 2018 
Terjadinya penurunan PDRB Aceh pada tahun 2015 sebesar $0,73 \%$ dikarenakan menurunnya investasi di Provinsi Aceh dan lambatnya pembangunan infrastruktur. Di sisi lain, peningkatan PDRB Aceh tertinggi yaitu sebesar 3,85\% pada tahun 2012 disebabkan meningkatnya sektor pertanian, kehutanan dan perikanan di beberapa kabupaten/kota di Provinsi Aceh.

\section{Analisis Location Quotient (LQ)}

Analisis LQ Kabupaten Aceh Timur

Berdasarkan hasil olahan data diperoleh bahwa sektor unggulan Kabupaten Aceh Timur adalah sektor pertambangan dan penggalian adalah sebesar 1,68 serta sektor pertanian, kehutanan dan perikanan sebesar 1,50, dimana sejak tahun 2010-2016 nilai LQ > 1, artinya peranan sektor pertanian, kehutanan dan perikanan serta sektor pertambangan dan penggalian lebih besar di Kabupaten Aceh Timur dari pada di Provinsi Aceh. Hal ini disebabkan karena sektor pertanian terutama perkebunan dan perikanan memegang peranan terpenting dalam kegiatan perekonomian Kabupaten Aceh Timur dengan kontribusi mencapai 45 persen pada tahun 2016 dan serta adanya penambahan unit industri pengolahan baru. Di sisi lain, industri pengolahan memiliki peranan sangat kecil dibandingkan dengan sektor lainnya yaitu sebesar 0,34 (LQ < 1) yang disebabkan oleh faktor teknologi.

\section{Analisis LQ Kota Langsa}

Berdasarkan hasil olahan data diperoleh hasil bahwa sektor jasa kesehatan dan kegiatan sosial memiliki nilai LQ rata-rata tertinggi yaitu sebesar 2,10. Hal ini dikarenakan meningkatnya jasa kesehatan di Kota Langsa khususnya rumah sakit serta pelayanan kesehatan lain dan meningkatnya aktivitas sosial.

Sektor lain yang merupakan sektor unggulan Kota Langsa penyediaan akomodasi dan makan minum dimana LQ rata-rata per tahun yaitu 2,02 (LQ > 1). Di sisi lain, sektor pertambangan dan penggalian memiliki peranan yang sangat kecil $(\mathrm{LQ}<1)$. Hal ini disebabkan karena Kota Langsa tak memiliki kekayaan pertambangan serta lahan-lahan yang dapat dipergunakan untuk penggalian.

\section{Analisis LQ Kabupaten Aceh Tamiang}

Berdasarkan hasil olahan data diperoleh bahwa sektor pertambangan dan penggalian memiliki nilai LQ rata-rata tertinggi yaitu sebesar 1,77. Hal ini dikarenakan terdapatnya tambang minyak bumi di Aceh Tamiang serta penggalian pasir dan tanah uruk. Sektor unggulan lain yang dimiliki Kabupaten Aceh Tamiang adalah pertanian, kehutanan dan perikanan dengan nilai sebesar 1,42 (LQ > 1). Hal ini dikarenakan banyak lahan-lahan pertanian dan perkebunan yang dimanfaatkan masyarakat dan mempunyai nilai ekonomis yang tinggi.

Sementara itu, sektor yang memiliki peranan yang kecil (LQ $<1)$ adalah administrasi pemerintahan, pertanahan dan jaminan sosial wajib dengan nilai LQ sebesar 0,46. Hal ini mengindikasikan bahwa sistem birokrasi di Kabupaten Aceh Tamiang harus terus ditingkatkan.

\section{Analisis LQ Aceh Bagian Timur}

Aceh Bagian Timur meliputi Kabupaten Aceh Timur, Kota Langsa, dan Kabupaten Aceh Tamiang. Pada Kabupaten Aceh Timur berdasarkan analisis LQ, sektor pertanian, kehutanan dan perikanan serta pertambangan dan penggalian, merupakan sektor unggulan. Di sisi lain, sektor unggulan tertinggi di Kota Langsa adalah sektor jasa kesehatan dan kegiatan sosial serta penyediaan akomodasi dan makan minum. Pada Kabupaten Aceh Tamiang, sector-sektor unggulannya adalah pertanian, kehutanan dan perikanan serta sektor pertambangan dan penggalian, atau sama dengan sektor unggulan yang dimiliki Kabupaten Aceh Timur.

Nilai PDRB rata-rata tertinggi yaitu pada Kabupaten Aceh Timur yaitu sebesar Rp 7,47 triliun rupiah, dan nilai PDRB tertinggi selanjutnya yaitu Kabupaten Aceh Tamiang sebesar Rp 4,83 triliun. Sedangkan Kota Langsa lebih rendah dibandingkan kedua Kabupaten tersebut karena memiliki nilai PDRB sebesar $R p$ 2,98 triliun. Hal ini menunjukkan bahwa Kabupaten Aceh Timur 
memberikan kontribusi paling tinggi terhadap nilai PDRB Aceh.

\section{Analisis Shift Share}

Analisis Shift Share merupakan teknik analisis yang diunakan untuk menganalisis sektor-sektor potensial unggulan atau sektor basis dalam kegiatan perekonomian nasional. Berdasarkan hasil perhitungan shift share maka dapat dijelaskan sebagai berikut:

1. Pertanian, Kehutanan, dan Perikanan.

Nilai rata-rata shift share Kabupaten Aceh Timur yaitu sebesar 119.778,53; Kota Langsa sebesar 11.158,63; dan, Kabupaten Aceh Tamiang sebesar 73.390,95. Hal ini menunjukkan bahwa nilai positif yang berarti bahwa sektor pertanian, kehutanan, dan perikanan Kabupaten Aceh Timur, Kota Langsa, dan Kabupaten Aceh Tamiang memberi kontribusi yang baik atau positif terhadap peningkatan PDRB Aceh.

2. Pertambangan dan Penggalian.

Nilai rata-rata shift share Kabupaten Aceh Timur yaitu sebesar -104.425,17, Kota Langsa sebesar -1.668,87, dan Kabupaten Aceh Tamiang memperoleh sebesar -90.998,41. Hal ini menunjukkan nilai negatif yang berarti bahwa sektor pertambangan dan penggalian Kabupaten Aceh Timur, Kota Langsa, maupun Kabupaten Aceh Tamiang tidak bisa memberikan kontribusi yang baik terhadap peningkatan PDRB Aceh.

3. Industri Pengolahan.

Nilai rata-rata shift share Kabupaten Aceh Timur yaitu sebesar -11.826,21, Kota Langsa sebesar -17.637,99, dan Kabupaten Aceh Tamiang memperoleh sebesar -15.495,90. Hal ini menunjukkan nilai negatif yang berarti bahwa sektor industri pengolahan Kabupaten Aceh Timur, Kota Langsa, dan Kabupaten Aceh Tamiang tak memberi kontribusi yang baik terhadap peningkatan PDRB Aceh.

4. Pengadaan Listrik dan Gas

Nilai rata-rata shift share Kabupaten Aceh Timur yaitu sebesar 711,18, Kota Langsa sebesar 340,19, dan Kabupaten
Aceh Tamiang sebesar 388,09. Hal ini menunjukkan nilai positif yang berarti bahwa sektor pengadaan listrik dan gas Kabupaten Aceh Timur, Kota Langsa, maupun Kabupaten Aceh Tamiang memberikan kontribusi yang rendah terhadap peningkatan PDRB Aceh.

5. Pengadaan Air, Pengelolaan Sampah, Limbah dan Daur Ulang.

Nilai rata-rata shift share Kabupaten Aceh Timur yaitu sebesar 135,96, Kota Langsa sebesar 97,14, dan Kabupaten Aceh Tamiang sebesar 107,45. Hal ini menunjukkan nilai positif yang berarti bahwa sektor pengadaan air, pengelolaan sampah, limbah serta daur ulang Kabupaten Aceh Timur, Kota Langsa, dan Kabupaten Aceh Tamiang memberi kontribusi yang rendah terhadap peningkatan PDRB Aceh.

6. Konstruksi.

Nilai rata-rata shift share Kabupaten Aceh Timur yaitu sebesar 30.625,16, Kota Langsa sebesar 19.968,70, dan Kabupaten Aceh Tamiang sebesar 19.263,29. Hal ini menunjukkan nilai positif yang berarti bahwa sektor konstruksi Kabupaten Aceh Timur, Kota Langsa, dan Kabupaten Aceh Tamiang memberikan kontribusi yang baik atas peningkatan PDRB Aceh.

7. Perdagangan Besar dan Eceran; Reparasi Mobil dan Sepeda Motor.

Nilai rata-rata shift share Kabupaten Aceh Timur yaitu sebesar 28.671,31, Kota Langsa sebesar 41.465,67, dan Kabupaten Aceh Tamiang sebesar 26.613,97. Hal ini menunjukkan nilai positif yang berarti bahwa sektor Perdagangan Besar dan Eceran; Reparasi Mobil dan Sepeda Motor Kabupaten Aceh Timur, Kota Langsa, maupun Kabupaten Aceh Tamiang memberikan kontribusi yang baik atau positif terhadap peningkatan PDRB Aceh.

8. Transportasi dan Pergudangan.

Nilai rata-rata shift share Kabupaten Aceh Timur yaitu sebesar 10.758,41, Kota Langsa sebesar 8.361,24, dan Kabupaten Aceh Tamiang memperoleh 
sebesar 5.743,21. Hal ini menunjukkan nilai positif yang berarti bahwa sektor Transportasi dan Pergudangan Kabupaten Aceh Timur, Kota Langsa, maupun Kabupaten Aceh Tamiang memberikan kontribusi yang baik atas peningkatan PDRB Aceh.

9. Penyediaan Akomodasi dan Makan Minum.

Nilai rata-rata shift share Kabupaten Aceh Timur yaitu sebesar 4.205,19, Kota Langsa sebesar 4.684,79, dan Kabupaten Aceh Tamiang sebesar 3.487,91. Hal ini menunjukkan nilai positif yang berarti bahwa sektor Penyediaan Akomodasi dan Makan Minum Kabupaten Aceh Timur, Kota Langsa, dan Kabupaten Aceh Tamiang memberikan kontribusi yang baik terhadap peningkatan PDRB Aceh.

10. Informasi dan Komunikasi.

Nilai rata-rata shift share Kabupaten Aceh Timur yaitu sebesar 7.437,06, Kota Langsa sebesar 7.694,58, dan Kabupaten Aceh Tamiang sebesar 7.140,70. Hal ini menunjukkan nilai positif yang berarti bahwa sektor Informasi dan Komunikasi Kabupaten Aceh Timur, Kota Langsa, dan Kabupaten Aceh Tamiang memberi kontribusi yang baik atas peningkatan PDRB Aceh.

11. Jasa Keuangan dan Asuransi.

Nilai rata-rata shift share Kabupaten Aceh Timur yaitu sebesar 5.673,67, Kota Langsa sebesar 4.619,96, dan Kabupaten Aceh Tamiang sebesar 2.354,77. Hal ini menunjukkan nilai positif yang berarti bahwa sektor Jasa Keuangan dan Asuransi Kabupaten Aceh Timur, Kota Langsa, dan Kabupaten Aceh Tamiang memberikan kontribusi yang baik atau positif terhadap peningkatan PDRB Aceh.

12. Real Estate.

Nilai rata-rata shift share Kabupaten Aceh Timur yaitu sebesar 14.888,73, Kota Langsa sebesar 8.351,39, dan Kabupaten Aceh Tamiang sebesar $11.025,81$. Hal ini menunjukkan nilai positif yang berarti bahwa sektor Real Estate Kabupaten Aceh Timur, Kota Langsa, dan Kabupaten Aceh Tamiang memberikan kontribusi yang baik atas peningkatan PDRB Aceh.

13. Jasa Perusahaan.

Nilai rata-rata shift share Kabupaten Aceh Timur yaitu sebesar 944,15, Kota Langsa sebesar 1.466,64, dan Kabupaten Aceh Tamiang sebesar 877,44. Hal ini menunjukkan nilai positif yang berarti bahwa sektor Jasa Perusahaan Kabupaten Aceh Timur, Kota Langsa, dan Kabupaten Aceh Tamiang memberikan kontribusi yang baik atas peningkatan PDRB Aceh.

14. Administrasi Pemerintahan, Pertahanan dan Jaminan Sosial Wajib.

Nilai rata-rata shift share Kabupaten Aceh Timur yaitu sebesar 27.197,43, Kota Langsa sebesar 12.763,91, dan Kabupaten Aceh Tamiang memperoleh sebesar 9.894,06. Hal ini menunjukkan nilai positif yang berarti bahwa sektor Administrasi Pemerintahan, Pertahanan dan Jaminan Sosial Wajib Kabupaten Aceh Timur, Kota Langsa, mauoun Kabupaten Aceh Tamiang memberikan kontribusi yang baik atas peningkatan PDRB Aceh.

15. Jasa Pendidikan.

Nilai rata-rata shift share Kabupaten Aceh Timur yaitu sebesar 6.141,36, Kota Langsa sebesar 3.027,96, dan Kabupaten Aceh Tamiang sebesar 4.427,15. Hal ini menunjukkan nilai positif yang berarti bahwa sektor Jasa Pendidikan Kabupaten Aceh Timur, Kota Langsa, maupun Kabupaten Aceh Tamiang memberikan kontribusi yang baik atas peningkatan PDRB Aceh.

16. Jasa Kesehatan dan Kegiatan Sosial.

Nilai rata-rata shift share Kabupaten Aceh Timur yaitu sebesar 12.126,70, Kota Langsa sebesar 10.826,77, dan Kabupaten Aceh Tamiang memperoleh sebesar 8.153,71. Hal ini menunjukkan nilai positif yang berarti bahwa sektor Jasa Kesehatan dan Kegiatan Sosial Kabupaten Aceh Timur, Kota Langsa, dan Kabupaten Aceh Tamiang memberi kontribusi yang baik atas peningkatan PDRB Aceh. 
17. Jasa Lainnya.

Nilai rata-rata shift share Kabupaten Aceh Timur yaitu sebesar 4.856,84, Kota Langsa sebesar 3.877,72, dan Kabupaten Aceh Tamiang sebesar 3.977,86. Hal ini menunjukkan nilai positif yang berarti bahwa sektor Jasa Lainnya Kabupaten Aceh Timur, Kota Langsa, maupun Kabupaten Aceh Tamiang memberikan kontribusi yang baik atas peningkatan PDRB Aceh.

Dari hasil-hasil analisis yang telah diuraikan, juga dapat dijelaskan bahwa:

1. Nilai national share Kabupaten Aceh Timur sebesar 7.478.832,8, Kota Langsa 2.986.984,2, maupun Kabupaten Aceh Tamiang sebesar 4.833.695,2 telah memberi pengaruh yang positif terhadap kegiatan perekonomian di Provinsi Aceh.

2. Nilai proporsional shift Kabupaten Aceh Timur bernilai negatif sebesar -0,250, Kota Langsa bernilai positif sebesar 4,467, dan Kabupaten Aceh Tamiang bernilai positif sebesar 3,068. Artinya, derajat perekonomian Kota Langsa dan Kabupaten Aceh Tamiang secara keseluruhan mengalami kemajuan.

3. Nilai differential shift Kabupaten Aceh Timur sebesar 119.778,53, Kota Langsa sebesar 41465,67 dan Kabupaten Aceh Tamiang sebesar 73.390,95. Hal ini berarti Kota Langsa memiliki keunggulan kompetitif regional yang lebih rendah dibandingkan Kabupaten Aceh Timur dan Aceh Tamiang.

\section{Analisis Daya Saing Kabupaten/Kota}

Berdasarkan analisis LQ diketahui bahwa Kabupaten Aceh Timur dan Kabupaten Aceh Tamiang memiliki kesamaan sektor unggulan yaitu sektor Pertanian, Kehutanan, dan Perikanan serta sektor Pertambangan dan Penggalian, sedangkan sektor ini tidak menjadi sektor unggulan di Kota Langsa karena ketersediaan lahan pertanian yang kurang memadai.

Berdasarkan analisis shift share yang telah dijelaskan bahwa sektor yang paling tinggi memberi peningkatan terhadap PDRB Aceh adalah sektor pertanian, kehutanan, dan perikanan, dan itu berada di Kabupaten Aceh Timur dan Kabupaten Aceh Tamiang, sedangkan Kota Langsa tidak termasuk. Sektor yang memberikan kontribusi terhadap peningkatan PDRB Aceh di Kota Langsa adalah sektor perdagangan besar dan eceran, reparasi mobil dan sepeda motor. Nilai shift share tertinggi di antara ketiga kabupaten/kota tersebut adalah Kabupaten Aceh Timur yaitu sebesar 119.778,53 pada sektor pertanian, kehutanan, dan perikanan. Hasil-hasil ini menunjukkan perekonomian Kabupaten Aceh Timur memberikan kontribusi yang besar terhadap PDRB Aceh dibandingkan dengan Kota Langsa dan Kabupaten Aceh Tamiang.

\section{KESIMPULAN}

Berdasarkan analisis data dan pembahasan maka dapat ditarik kesimpulan sebagai berikut:

1. Berdasarkan perhitungan LQ diketahui bahwa sektor unggulan Kabupaten Aceh Timur adalah sektor pertanian, kehutanan, dan perikanan serta sektor pertambangan dan penggalian dengan LQ sejak tahun 2010-2016 diperoleh rata-rata masingmasing sebesar 1,50 dan 1,68 (LQ > 1). Hal ini dikarenakan ketersediaan lahan pertanian begitu besar di Kabupaten Aceh Timur serta kandungan mineral yang ada di Kabupaten Aceh Timur meningkatkan perekonomian daerah.

2. Sektor unggulan Kota Langsa adalah sektor jasa kesehatan dan kegiatan sosial, sektor penyediaan akomodasi makan dan minum dengan LQ rata-rata sejak tahun 2010-2016 masing-masing LQ $>1$ atau masing-masing sebesar 2,10 dan 2,02. Hal ini dikarenakan meningkatnya jasa kesehatan di Kota Langsa khususnya rumah sakit serta pelayanan kesehatan lainnya dan meningkatnya aktivitas sosial.

3. Sektor unggulan Kabupaten Aceh Tamiang adalah pertanian, kehutanan dan perikanan serta sektor pertambangan dan penggalian dengan LQ rata-rata sejak tahun 2010-2016 masing-masing sebesar 1,42 dan 1,77 (LQ > 1). Hal ini karena banyaknya lahan-lahan pertanian maupun perkebunan yang dimanfaatkan oleh pihak 
masyarakat dan memiliki nilai ekonomis yang tinggi.

4. Berdasarkan hasil analisis shift share dijelaskan bahwa sektor yang paling tinggi memberikan peningkatan terhadap PDRB Aceh adalah sektor pertanian, kehutanan, dan perikanan, dan itu berada di Kabupaten Aceh Timur dan Kabupaten Aceh Tamiang, sedangkan Kota Langsa tidak termasuk. Sektor yang memberikan kontribusi terhadap peningkatan PDRB Aceh di Kota Langsa adalah sektor perdagangan besar dan eceran, reparasi mobil dan sepeda motor.

\section{DAFTAR PUSTAKA}

Adisasmita, R. 2005. Dasar-Dasar Ekonomi Wilayah. Yogyakarta: Graha Ilmu.

Ambardi, U.M. dan Socia, P. 2002. Pengembangan Wilayah dan Otonomi Daerah. Jakarta: Pusat Pengkajian Kebijakan Pengembangan Wilayah (P2KTPW-BPPT).

Arsyad, L. 1999. Pengantar Perencanaan dan Pembangunan Ekonomi Daerah. Yogyakarta: BPFE. Badan Pusat Statistik.

Arsyad, L. 2004. Ekonomi Pembangunan. Edisi Keempat. Yogyakarta: STIE YKPN.

Budiharsono. 2008. Pengantar Perencanaan dan Pembangunan Daerah. Yogyakarta: YKPN.

Emawati, Y. 2013. Pembangunan Daerah di Indonesia. Jakarta: Salemba Empat.

Faisal. 2014. Analisis Sektor Unggulan Perekonomian Kota Banda Aceh. Jurnal Ekonomi dan Kebijakan Publik Indonesia. Vol. 1, No. 1, hal. 8-15.

Firman, A. 2007. Analisis Dampak Investasi Sektor Peternakan terhadap Perekonomian di Jawa Tengah. http://www.Pustaka.Unpad.ac.id. Diunduh tanggal 9 Desember 2018.

Hajeri, Yurisinthae, E. dan Dolorosa, E. 2015. Analisis Penentuan Sektor Unggulan Perekonomian di Kabupaten Kubu Raya. Jurnal Ekonomi Bisnis dan
Kewirausahaan, Vol. 4, No. 2, hal. 253-269.

Khusaini, M. 2006. Ekonomi Publik: Desentralisasi Fiskal dan Pembangunan Daerah. Malang: BPFE UB.

Kuncoro, M. 2004. Otonomi \& Pembangunan Daerah, Reformasi, Perencanaan, strategi, dan Peluang. Jakarta: Erlangga.

Mangilaleng, E.J., Rotinsulu, D. dan Rompas, W. 2015. Analisis Sektor Unggulan Kabupaten Minahasa Selatan. Jurnal Berkala Ilmiah Efisiensi. Vol. 15, No. 4, hal. 193-205.

Octaria, R.N. dan Hidayat, P. 2015. Analisis Sektor Unggulan di Kota Medan. Jurnal Ekonomi dan Keuangan, Vol. 3, No.1, hal. 59-71.

Putra, M.F. 2011. Studi Kebijakan Publik dan Pemerintahan dalam Perspektif Kuantitatif. Cetakan Pertama, April 2011. Malang: Universitas Brawijaya (UB) Press.

Rachbini, D.J. 2001. Pembangunan Ekonomi dan SDM. Jakarta: PT. Grasindo.

Rustiadi. 2007. Perencanaan dan Pengembangan Wilayah. Yogyakarta: BPFE.

Sirojuzilam dan Mahalli, K. 2010. Regional. Pembangunan, Perencanaan dan Ekonomi. Medan: USU Press.

Sirojuzilam. 2008. Disparitas Ekonomi dan Perencanaan Regional, Ketimpangan Ekonomi Wilayah Barat dan Wilayah Timur Provinsi Sumatera Utara. Pustaka Bangsa Press.

Sjafrizal. 2008. Ekonomi Regional: Teori dan Aplikasi. Padang: Baduose Media.

Soeparmoko. 2002. Ekonomi Publik Untuk Keuangan dan Pembangunan Daerah. Edisi Pertama. Yogyakarta: Andi.

Suyatno. 2000. Analisa Economic Base terhadap Pertumbuhan Ekonomi Daerah Tingkat II Wonogiri: Menghadapi Implementasi UU No. 22/1999 dan UU No. 5/1999. Jurnal 
Ekonomi Pembangunan. Vol. 1, No. 2, hal. 144-159.

Tambunan, T.T.H. 2001. Perekonomian Indonesia: Teori Dan Temuan Empiris. Jakarta: Ghalia Indonesia.

Tarigan, R. 2014. Ekonomi Regional Teori dan Aplikasi. Edisi Revisi, Cetakan Ketujuh, Jakarta: PT. Bumi Aksara.
Wayan Mardiana, I,. 2017. Analisis Pergeseran Struktur Ekonomi dan Sektor Unggulan di Kabupaten Tabanan Provinsi Bali. Skripsi, Denpasar: Fakultas Ekonomi dan Bisnis Universitas Udayana.

Widodo, T. 2006. Perencanaan Pembangunan: Aplikasi Komputer. Yogyakarta: UPP STIM YKPN. 